\title{
How Is Your Cleaning Behavior? House Dust Mites and Its Relationship to Allergic Rhinitis
}

\author{
Bagaimana Perilaku Kebersihan Kita? \\ Tungau Debu Rumah dan Hubungannya dengan Rinitis Alergi
}

\author{
Kahfi K. Illahi ${ }^{1}$, Erma Sulistyaningsih ${ }^{2}$, Erfan Efendi ${ }^{3}$ \\ ${ }^{1,2,3}$ Bagian Kedokteran, Universitas Jember, Jember
}

DOI: $10.24252 /$ al-sihah.v13i2.22041

Received: 12 July 2021 / In Reviewed: 10 December 2021 / Accepted: 26 December 2021 / Available online: 30 December 2021 (C) The Authors 2021. This is an open access article under the CC BY-NC-SA 4.0 license

\begin{abstract}
The main allergen of allergic rhinitis is house dust mites (HDM), that often found in humid room conditions and furnitures. The health behaviour consists of knowledge, attitude, and practice is closely related to the occurrence of disease including allergic rhinitis. One of the methods to screen allergic rhinitis is the score for allergic rhinitis (SFAR) questionnaire. This study aimed to determine the relationship between behaviour (knowledge, attitude, and practice) on house dust mites and the SFAR score. This was an analytical observational study on female population age 17-34 years old in Jember District. As many as 141 respondents were selected using the purposive sampling technique based on inclusion and exclusion criteria. Data were collected using an online behaviour questionnaire and the SFAR. The primary data were analyzed statistically by chi-square test with a significance value of $p<0.05$. The results showed that 46 respondents $(32.62 \%)$ had an SFAR score $>$ 7, indicated allergic rhinitis symptoms. The majority of respondents (76 people or 54\%) had sufficient knowledge about HDM, as many as 132 respondents (93.62\%) had a good attitude towards HDM and 94 respondents (66.67\%) had a good practice towards HDM. Statistical analysis showed that there was a relationship between knowledge, attitude, and practice on HDM and the SFAR score, each with the value of $p=0.000$. In conclusion, good knowledge, attitude, and practice to HDM would decrease the HDM population resulting in reduce of allergic rhinitis risk, that could be screened by SFAR.
\end{abstract}

\section{ABSTRAK}

Alergen utama rinitis alergi adalah Tungau Debu Rumah (TDR) yang sering ditemukan pada ruangan yang lembap dan beberapa perabot rumah tangga. Perilaku kesehatan yang terdiri dari pengetahuan, sikap dan praktik sangat erat berhubungan dengan terjadinya penyakit, termasuk rinitis alergi. Salah satu metode yang digunakan untuk skrining rinitis alergi adalah Score for Allergic Rhinitis (SFAR). Penelitian ini bertujuan untuk mengetahui hubungan antara perilaku terhadap TDR yang mencakup pengetahuan, sikap, dan tindakan dengan skor rinitis alergi. Penelitian observasional analitik dilakukan pada populasi perempuan berusia 17-34 tahun di Kabupaten Jember, dan didapatkan 141 responden yang dipilih dengan teknik purposive sampling sesuai dengan kriteria inklusi dan ekslusi. Data dikumpulkan menggunakan kuesioner perilaku terhadap TDR dan skor rinitis alergi yang disebarkan secara online. Data dianalisis dengan uji chi-square dengan signifikansi $\mathrm{p}<0,05$. Hasil penelitian menunjukkan bahwa sebanyak 46 dari 141 responden (32,62\%) mempunyai skor SFAR $\geq 7$ yang mengindikasikan gejala rhinitis alergi. Mayoritas responden (76 orang atau $54 \%$ ) memiliki pengetahuan yang cukup terhadap TDR, sebesar 132 responden $(93,62 \%)$ memiliki sikap yang baik terhadap TDR dan 94 responden $(66,67 \%)$ memiliki tindakan yang baik terhadap TDR. Analisis statistik menunjukkan terdapat hubungan antara pengetahuan, sikap dan tindakan tentang TDR dengan SFAR, masing-masing dengan nilai $\mathrm{p}=0.000$. Dapat disimpulkan bahwa pengetahuan, sikap dan tindakan yang baik terhadap TDR akan dapat menurunkan populasi TDR sehingga dapat menurunkan risiko terjadinya rinitis alergi yang dapat diukur dengan skor SFAR

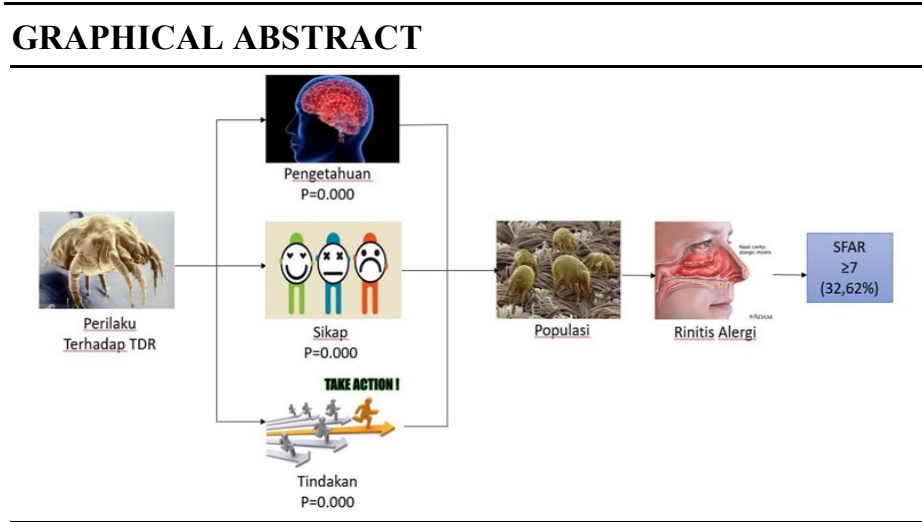

Keyword

allergic rhinitis; health behaviour; house dust mites; score for allergic rhinitis

Kata Kunci:

perilaku kesehatan; rinitis alergi; skor untuk rinitis alergi; tungau debu rumah

* Correspondence

Jl. Kalimantan No.37 Jember, Jawa Timur, 68121

Email: sulistyaningsih.fk@unej.ac.id 


\section{PENDAHULUAN}

Rinitis alergi merupakan penyakit inflamasi mukosa hidung akibat induksi oleh immunoglobulin E (IgE) karena pajanan alergen (Susanti et al., 2016) dengan gejala diantaranya bersin berulang, hidung tersumbat, hidung berair, dan hidung gatal (Rafi et al., 2015). Sekitar 600 juta penduduk dunia menderita rinitis alergi, prevalensi rinitis alergi di Asia Tenggara sebesar 5,5 - 45,1 \% (Septriana et al., 2018). Pada tahun 2013 terdapat 1.018 kasus rinitis alergi di RSUD Dr. Soetomo Surabaya dan meningkat 10 sampai 20 kasus setiap bulannya, sedangkan data RSUD Dr. Saiful Anwar Malang terdapat 132 kasus baru sepanjang tahun 2015 (Hartini, 2016). Reinhard et al. (2013) menyatakan bahwa prevalensi rinitis alergi tertinggi berada pada kelompok usia 21-30 tahun.

Klasifikasi rinitis alergi berdasarkan lamanya gejala, yaitu intermiten bila gejala kurang dari empat hari per minggu atau kurang dari empat minggu dan persisten jika gejala lebih dari empat hari per minggu dan lebih dari empat minggu. Rinitis alergi juga diklasifikasikan berdasarkan kualitas hidup, yaitu ringan apabila tidak mengganggu aktivitas sehari-hari dan berat apabila mengganggu aktivitas sehari-hari (Nisa, 2017). Saat ini, pemeriksaan tes kulit alergi merupakan gold standard untuk diagnosis rhinitis alergi. Tetapi, para ahli mengembangkan instrumen Score for allergic rhinitis (SFAR) yang berupa sistem skor berstandar untuk menskrining rinitis alergi khususnya di negara berkembang. Hasil skor maksimal SFAR adalah 16 dan skor minimal untuk menegakkan diagnosis rinitis alergi adalah 7
(Ologe et al., 2013). Instrumen SFAR dapat memisahkan rinitis alergi dengan rinitis yang lain seperti rinitis infeksi, rinitis okupasional, rinitis yang diinduksi obat, rinitis hormonal, dan rinitis idiopatik. SFAR mudah digunakan dan mempunyai spesifisitas dan sensitivitas tinggi sehingga dapat digunakan oleh non-spesialis dan terlepas dari ketiadaan pemeriksaan medis. Hasil instrumen ini mendekati gold standard diagnosis rinitis alergi yaitu tes kulit alergi (Piau et al., 2010).

Rinitis alergi disebabkan oleh alergen yang terhirup atau aeroalergen dan alergen yang termakan atau alergen ingestan. Aeroalergen seperti jamur, tungau debu rumah (TDR), dan bulu hewan peliharaan (European Academy of Allergy and Clinival Immunology, 2014; Bousquet et al., 2012). World Health Organization (WHO) menyampaikan bahwa sekitar 50 $80 \%$ kasus asma dan rinitis alergi di seluruh dunia disebabkan oleh Tungau Debu Rumah (TDR) terutama dari famili Pyroglyphidae spesies Dermatophagoides pteronyssinus dan Dermatophagoides farinae (Hohakay et al., 2017). Calderon et al. (2015) menjelaskan hubungan antara paparan alergen TDR dengan kejadian alergi, dimana paparan alergen TDR yang terdapat pada $10 \mathrm{mcg} / \mathrm{g}$ debu karpet memiliki risiko tinggi untuk menimbulkan alergi (Natalia, 2015). Hasil penelitian di Iran menyebutkan bahwa spesies TDR yang sering teridentifikasi adalah D. pteronyssinus $(63,1 \%)$, D. farinae $(32,8$ \%), dan D. evansi (4.1\%) (Sun et al., 2013). Dari 345 sampel debu rumah di Beijing, China, $64 \%$ teridentifikasi tungau, dengan spesies utama $D$. farinae. Populasi TDR 
yang tertinggi di beberapa kota di Indonesia seperti Bali, Jakarta, dan Manado adalah Dermatophagoides sp. (Haqi, 2016). Sumber alergen yang dominan di Indonesia berasal dari Dermatophagoides sp. yaitu alergen kelompok 1 yang terdiri dari Der p1 yang diproduksi oleh $D$. pteronyssinus dan Der f1 yang dihasilkan oleh D. farinae. Semakin kecil ukuran alergen maka semakin dalam penetrasi ke organ pernapasan. Alergen tersebut akan berikatan dengan reseptor CD23 dan CD25 sehingga mengakibatkan epitel rusak dan mengaktifkan proses inflamasi. Sel Th2 yang aktif mengakibatkan pelepasan sitokin pro-inflamasi oleh sel epitel bronkial, sel mast, dan basofil sehingga menimbulkan gejala alergi (Mantu et al., 2016; Fassio \& Guagnini, 2018; Yolazenia et al., 2019). Alergen kelompok 2, yaitu Der p2 yang lebih kuat terhadap suhu panas memiliki struktur yang homolog dengan MD2, suatu pengikat lipid, kofaktor Toll-like Receptor 4 (TLR4), sehingga inflamasi saluran pernapasan oleh Der p2 terjadi karena mekanisme TLR4 yang mengakibatkan terjadinya respons Th2 (Natalia, 2015).

Pengetahuan, sikap dan praktik yang membentuk perilaku kesehatan berperan penting dalam menentukan risiko terjadinya rhinitis alergi. Penelitian di Arab Saudi dan India menunjukkan bahwa pengetahuan yang kurang terkait dengan rhinitis alergi mengakibatkan sikap dan praktik yang buruk terhadap rinitis alergi (Alreshidi et al, 2017; Rajasekaran \& Ghosh, 2018). Penelitian Purba et al. (2013) menunjukkan bahwa perilaku terhadap TDR mempengaruhi kepadatan pop- ulasi TDR dan Wang et al. (2014) di Wuhan juga melaporkan tingginya alergen TDR di dalam rumah berhubungan dengan beratnya gejala rhinitis alergi. Tujuan penelitian ini adalah untuk mengetahui hubungan antara perilaku yang terdiri dari pengetahuan, sikap, dan praktik terhadap TDR dengan kejadian rinitis alergi yang dideteksi dengan SFAR pada masyarakat Kabupaten Jember.

\section{METODE PENELITIAN}

Penelitian ini merupakan penelitian observasional analitik dengan desain crosssectional. Penelitian dilakukan pada bulan Februari-April 2021. Populasi penelitian ini adalah perempuan berusia 17-34 tahun di Kabupaten Jember. Jumlah sampel penelitian sebanyak 141 responden dihitung menggunakan rumus Lemeshow dan dipilih menggunakan teknik purposive sampling. Kriteria eksklusi penelitian antara lain mempunyai peliharaan anjing atau kucing, merokok atau tinggal bersama perokok, bekerja di salah satu sektor (pabrik, pertanian, dan perkebunan). Penelitian ini telah mendapatkan ijin penelitian dari Komisi Etik Penelitian Fakultas Kedokteran Universitas Jember Nomor: 1472/H25.1.11/KE/2021.

Data primer yang dikumpulkan menggunakan kuesioner adalah data karakteristik dasar yaitu umur dan pekerjaan, perilaku terhadap TDR yang terdiri atas pengetahuan, sikap, dan tindakan yang disusun berdasarkan penelitian sebelumnya (Mapanawang, 2013) serta skor SFAR yang diadopsi dari penelitian sebelumnya (Ologe et al, 2013; Piau et al, 2010). 
Tabel 1

Karakteristik Responden Penelitian

\begin{tabular}{|c|c|c|}
\hline Karakteristik & $\mathrm{n}$ & $\%$ \\
\hline \multicolumn{3}{|l|}{ Usia } \\
\hline $17-21$ & 98 & 69,5 \\
\hline $22-26$ & 20 & 14,1 \\
\hline $27-30$ & 13 & 9,2 \\
\hline $31-34$ & 10 & 7,2 \\
\hline \multicolumn{3}{|l|}{ Pekerjaan } \\
\hline Mahasiswa & 85 & 60,3 \\
\hline Pelajar & 21 & 14,9 \\
\hline Ibu Rumah Tangga & 7 & 5 \\
\hline Guru & 4 & 2,8 \\
\hline Pegawai & 3 & 2,1 \\
\hline Lainnya & 21 & 14,9 \\
\hline Total & 141 & 100 \\
\hline
\end{tabular}

Kuesioner disebarkan secara online dan dikonfirmasi kebenarannya dengan menghubungi responden secara langsung melalui telepon. Data dianalisis dengan SPSS version 26.0 dan uji statistik dengan chi-square test karena skala data ordinal dengan nilai signifikansi $\mathrm{p}<0,05$.

\section{HASIL PENELITIAN}

Tabel 1 menunjukkan karakteristik responden penelitian ini yang terdiri dari data usia dan pekerjaan. Mayoritas responden $(69,5 \%)$ adalah remaja muda dengan usia 17 - 21 tahun dan paling sedikit usia dewasa $31-34$ tahun sebesar $7,2 \%$. Jenis pekerjaan terbanyak adalah mahasiswa sebesar $60,3 \%$ dan paling sedikit pegawai sebesar $2,1 \%$.

Tabel 2 menampilkan distribusi hasil skor SFAR berdasarkan karakteristik usia dan pekerjaan. Responden diduga kuat mengalami rinitis alergi bila skor SFAR $>7$. Sebanyak 46 dari 141 responden (32,62 \%) mempunyai skor SFAR $>7$, dimana sebagian besar responden $(65,2 \%)$ dengan skor $\geq$ 7 berada di usia 17-21 tahun dan sebesar
$58,7 \%$ merupakan mahasiswa. Responden dengan SFAR $>7$ paling sedikit pada kelompok umur 31 - 34 tahun sebesar 4,4 \% dan dari jenis pekerjaan ibu rumah tangga dan pegawai, masing-masing sebesar $2,1 \%$.

Tabel 3 menunjukkan data distribusi masing-masing aspek perilaku yaitu pengetahuan, sikap dan tindakan terhadap TDR yang didapat melalui kuesioner. Sebagian besar responden (76 orang atau $54 \%$ ) mempunyai pengetahuan cukup tentang TDR, mayoritas responden (132 orang atau 93,62 \%) mempunyai sikap baik terhadap TDR, dan sebagian besar (94 orang atau $66,67 \%)$ responden mempunyai tindakan baik.

Tabel 4 menunjukkan tabulasi silang masing-masing aspek perilaku, yaitu pengetahuan, sikap dan tindakan terhadap TDR dihubungkan dengan skor SFAR serta analisis statistiknya. Sebanyak 37 responden (48,7\%) dengan pengetahuan yang cukup tentang TDR mempunyai skor SFAR $>7$ dan tidak ada responden dengan pengetahuan baik mempunyai mempunyai skor SFAR > 7. Dan sebaliknya, tidak ada re- 
Tabel 2

Skor SFAR Responden Berdasarkan Karakteristik Usia dan Pekerjaan

\begin{tabular}{|c|c|c|c|c|}
\hline \multirow{3}{*}{ Kategori } & \multicolumn{4}{|c|}{ Hasil skor SFAR } \\
\hline & \multicolumn{2}{|c|}{ Skor $\geq 7$} & \multicolumn{2}{|c|}{ Skor $<7$} \\
\hline & $\mathrm{n}$ & $\%$ & $\mathrm{n}$ & $\%$ \\
\hline \multicolumn{5}{|l|}{ Usia } \\
\hline $17-21$ & 30 & 65,2 & 68 & 71,5 \\
\hline $22-26$ & 8 & 17,3 & 12 & 12,6 \\
\hline $27-30$ & 6 & 13,1 & 7 & 7,4 \\
\hline $31-34$ & 2 & 4,4 & 8 & 8,4 \\
\hline \multicolumn{5}{|l|}{ Pekerjaan } \\
\hline Mahasiswa & 27 & 58,7 & 58 & 61 \\
\hline Pelajar & 8 & 17,4 & 13 & 13,7 \\
\hline Ibu Rumah Tangga & 1 & 2,1 & 6 & 6,3 \\
\hline Guru & 2 & 4,3 & 2 & 2,1 \\
\hline Pegawai & 1 & 2,1 & 2 & 2,1 \\
\hline Lainnya & 7 & 15,4 & 14 & 14,8 \\
\hline Total & 46 & 100 & 95 & 100 \\
\hline
\end{tabular}

sponden dengan pengetahuan kurang yang mempunyai skor SFAR $<7$ dimana sebagian besar responden (56 orang) yang mempunyai skor SFAR $<7$ berpengetahuan baik tentang TDR. Pada aspek sikap terkait TDR, sebagian besar responden dengan skor SFAR $>7$ mempunyai sikap baik, tetapi hasil ini didukung data bahwa tidak ada responden dengan sikap buruk terkait TDR yang mempunyai skor SFAR < 7. Hasil pada aspek tindakan menunjukkan bahwa tidak ada responden dengan tindakan baik terhadap TDR yang mempunyai skor SFAR $>7$. Analisis statistik untuk mengetahui hubungan antara pengetahuan tentang TDR, sikap terhadap TDR dan tindakan terkait TDR dengan skor SFAR menggunakan chi-square test menunjukkan hasil masing-masing $p=0,000$ yang berarti signifikan.

\section{PEMBAHASAN}

Penelitian ini menganalisis hubungan antara aspek-aspek perilaku yaitu pengetahuan, sikap dan tindakan terkait
TDR dengan skor SFAR pada masyarakat Kabupaten Jember. Kriteria inklusi yang ditetapkan dalam penelitian ini adalah jenis kelamin perempuan. Hal ini sesuai dengan penelitian sebelumnya bahwa ada pergeseran prevalensi penderita rinitis alergi pada anak-anak dan dewasa, dimana pada anak-anak yang lebih tinggi pada lakilaki dan pada dewasa menjadi lebih tinggi pada perempuan (Frohlich et al., 2002). Responden penelitian ini juga didominasi usia remaja muda yaitu 17 - 21 tahun dengan mayoritas pekerjaan sebagai mahasiswa. Hal ini diduga karena instrumen yang digunakan dalam penelitian ini berupa kuesioner yang disebarkan secara online mengingat kondisi pandemi covid-19 yang terjadi mulai awal 2020 sampai sekarang. Mahasiswa merupakan kelompok usia yang aktif menggunakan media sosial, sesuai dengan data dari Asosiasi Penyelenggara Jasa Internet Indonesia pada tahun 2017 bahwa penggunaan tertinggi media sosial di Indonesia yaitu remaja sebesar 75,5\%. Selain itu, pemilihan kriteria inklusi 
Tabel 3

Distribusi Aspek Pengetahuan, Sikap dan Tindakan terhadap TDR

\begin{tabular}{|c|c|c|}
\hline Kategori & $\mathrm{n}$ & $\%$ \\
\hline \multicolumn{3}{|l|}{ Pengetahuan tentang TDR } \\
\hline Baik & 56 & 40 \\
\hline Cukup & 76 & 54 \\
\hline Kurang & 9 & 6 \\
\hline \multicolumn{3}{|l|}{ Sikap terhadap TDR } \\
\hline Baik & 132 & 93,62 \\
\hline Buruk & 9 & 6,38 \\
\hline \multicolumn{3}{|l|}{ Tindakan terhadap TDR } \\
\hline Baik & 94 & 66,67 \\
\hline Buruk & 47 & 33,33 \\
\hline Total & 141 & 100 \\
\hline
\end{tabular}

penelitian berupa usia 17 - 34 tahun didasarkan pada hasil penelitian sebelumnya bahwa rentang usia 15 - 25 tahun merupakan usia terbanyak penderita rinitis alergi (Yolazenia et al, 2019). Hal ini juga sesuai dengan hasil penelitian bahwa sebagian besar responden dengan skor SFAR $\geq 7$ berasal dari kelompok rentang usia 17 - 21 tahun. Diketahui bahwa prevalensi rinitis alergi menurun dengan bertambahnya usia. Penyakit ini terjadi ketika balita, puncaknya saat usia 20 tahunan dan menurun saat usia 30 tahun (Yolazenia et al, 2019). Sulistyaningsih et al. (2021) melaporkan 11 dari 30 responden ibu rumah tangga di Sumbersari Kabupaten Jember mempunyai skor SFAR $\geq 7$, yang mengindikasikan menderita rinitis alergi.

Perilaku kesehatan berperan penting dalam menimbulkan masalah kesehatan atau penyakit. Ada tiga aspek perilaku, yaitu pengetahuan, sikap, dan praktik/tindakan (Irwan, 2017). Ketiga aspek perilaku tersebut merupakan determinan penting yang dapat menimbulkan masalah kesehatan termasuk rinitis alergi. Penelitian ini menun- jukkan bahwa mayoritas responden memiliki pengetahuan yang cukup tentang TDR. Pengetahuan merupakan hasil penginderaan seseorang yang terjadi melalui proses belajar, hal tersebut dipengaruhi oleh beberapa faktor antara lain lingkungan, seperti contoh apabila individu mempunyai kerabat yang mengalami rinitis alergi dimana lebih dari $80 \%$ alergi disebabkan oleh TDR, maka individu tersebut akan lebih waspada dan akan memiliki pengetahuan yang lebih terhadap TDR dan rinitis alergi. Selain itu, kondisi saat ini dengan fasilitas kemudahan dan kecepatan mengakses informasi menggunakan internet, khususnya remaja sekarang gadget dan teknologi sehingga dengan mudah mencari informasi tersebut Tetapi, hasil penelitian ini berbeda dengan penelitian Mapanawang (2013) yang mendapatkan hasil 85 responden $(89,95 \%)$ memiliki pengetahuan yang buruk. Perbedaan ini diduga karena pengambilan data yang terpaksa dilakukan menggunakan kuesioner online akibat pandemi Covid-19, sehingga tidak ada pengawasan langsung saat responden mengisi kuesioner. Tetapi 
Tabel 4

Tabulasi Silang Pengetahuan, Sikap dan Tindakan terhadap Skor SFAR dan Analisis Statistiknya

\begin{tabular}{|c|c|c|c|c|c|c|c|}
\hline \multirow{3}{*}{ Kategori } & \multicolumn{4}{|c|}{ Skor SFAR } & \multirow{2}{*}{\multicolumn{2}{|c|}{ Total }} & \multirow{3}{*}{$p$-value } \\
\hline & \multicolumn{2}{|c|}{ Skor $\geq 7$} & \multicolumn{2}{|c|}{ Skor $<7$} & & & \\
\hline & $\mathrm{n}$ & $\%$ & $\mathrm{n}$ & $\%$ & $\mathrm{n}$ & $\%$ & \\
\hline \multicolumn{8}{|l|}{ Pengetahuan } \\
\hline Kurang & 9 & 10 & 0 & 0 & 9 & 100 & 0,000 \\
\hline Cukup & 37 & 48,7 & 39 & 51,3 & 76 & 100 & \\
\hline Baik & 0 & 0 & 56 & 100 & 56 & 100 & \\
\hline \multicolumn{8}{|l|}{ Sikap } \\
\hline Buruk & 9 & 100 & 0 & 0 & 9 & 100 & 0,000 \\
\hline Baik & 37 & 28 & 95 & 92 & 132 & 100 & \\
\hline \multicolumn{8}{|l|}{ Tindakan } \\
\hline Buruk & 46 & 97,9 & 1 & 2,1 & 47 & 100 & 0,000 \\
\hline Baik & 0 & 0 & 94 & 100 & 94 & 100 & \\
\hline Jumlah & 46 & 32,6 & 95 & 67,4 & 141 & 100 & \\
\hline
\end{tabular}

hal ini telah diminimalisir dengan melakukan konfirmasi melalui telepon secara langsung kepada setiap responden.

Mayoritas responden mempunyai sikap yang baik terkait dengan TDR, hasil ini serupa dengan penelitian Mapanawang (2013). Sikap merupakan bentuk reaksi terhadap suatu objek spesifik yang melibatkan faktor pendapat dan emosi yang bersangkutan seperti senang-tidak senang, setujutidak setuju, baik-tidak baik, dan sebagainya (Irwan, 2017). Sikap baik ini terjadi karena masyarakat sadar akan pentingnya menjaga kebersihan lingkungan secara umum, meskipun pengetahuan terhadap TDR masih kurang atau cukup. Sikap yang baik dan tanggap terhadap kebersihan lingkungan secara tidak langsung juga berperan dalam sikap baik terhadap TDR. Seperti diketahui bahwa TDR banyak ditemukan pada tempat yang lembab dan berdebu di dalam rumah. TDR dapat bertahan hidup pada suhu $25^{\circ} \mathrm{C}$ dan kelembaban rerata $75 \%$ (Natalia, 2015). Makanan utama TDR adalah skuama atau serpihan kulit manusia sehingga TDR ser- ing ditemukan di tempat tidur. Upaya pencegahan yang dapat dilakukan untuk mencegah populasi TDR yaitu menjaga sirkulasi udara dan kondisi ruangan tetap kering, rajin membersihkan perabotan rumah tangga setiap hari menggunakan vacuum cleaner atau lap basah, mengganti peralatan kamar tidur secara teratur seminggu sekali seperti sarung bantal, sprei, sarung guling, dan selimut, menyimpan pakaian atau buku pada lemari yang tertutup, dan menjemur kasur seminggu sekali (Haqi, 2016). Sikap baik ini akan dilanjutkan dalam tindakan yang baik terhadap TDR, sesuai dengan teori perilaku, sehingga tingkat penyakit alergi yang disebabkan TDR salah satunya rinitis alergi akan berkurang, sesuai hasil yang diperoleh.

Mayoritas responden memiliki tindakan yang baik terkait TDR. Tindakan ini berupa upaya-upaya yang dilakukan untuk mengurangi populasi TDR dalam rumah seperti menyapu lantai, mengepel, membersihkan perabotan dengan cara yang benar, mengganti sprei dan sarung bantal, menjemur kasur, bantal, guling, membuka 
jendela, meletakkan pakaian pada lemari tertutup, meletakkan buku pada rak buku tertutup. Tindakan lain yang dilakukan antara lain menggunakan masker saat membersihkan perabot rumah, tidak menggunakan kemoceng untuk membersihkan perabot rumah, mencuci pakaian dengan air panas, tidak menggunakan pelembab ruangan, dan tindakan hati-hati yang dilakukan saat anggota keluarga menderita alergi seperti melapisi kasur dengan plastik dan segera membawa ke pusat kesehatan bila mengalami serangan. Hasil penelitian ini serupa dengan penelitian sebelumnya di Kabupaten Manado oleh Mapanawang (2013) dan masyarakat Kecamatan Tikala dan Sario oleh Purba (2013). Wang et al. (2014) pada penelitian di Wuhan juga menunjukkan tingginya konsentrasi allergen berhubungan dengan lamanya kasur dan bantal yang digunakan dan mempengaruhi beratnya gejala klinis rinitis alergi. Hasil tindakan yang baik terhadap TDR ini diduga karena semua responden adalah perempuan dimana mereka cenderung memegang peran penting untuk menjaga dan mengatur kebersihan lingkungan rumah. Tindakan baik ini mengakibatkan turunnya kejadian rinitis alergi, sesuai dengan hasil penelitian bahwa tidak ada responden dengan tindakan baik yang mempunyai skor SFAR > 7. El-Ghitany \& Abd El-Salam (2012) juga menunjukkan pentingnya praktik intervensi lingkungan untuk menurunkan populasi TDR guna menurunkan gejala pasien asma.

Hasil penelitian ini menunjukkan bahwa terdapat hubungan antara perilaku masyarakat Kabupaten Jember terhadap skor SFAR. Penelitian ini menekankan peran besar perilaku yang terdiri dari aspek pengetahuan, sikap dan tindakan terkait TDR dengan terjadinya penyakit rinitis alergi.

\section{KESIMPULAN}

Penelitian ini menyimpulkan bahwa masyarakat Kabupaten Jember memiliki pengetahuan yang cukup, sikap yang baik, dan tindakan yang baik terkait dengan TDR dan upaya yang dilakukan untuk meminimalkan populasinya sehingga dapat menurunkan kejadian penyakit rinitis alergi. Masing-masing aspek perilaku berhubungan dengan kejadian rinitis alergi. Keterbatasan pada penelitian ini menggunakan crosssectional, sehingga penelitian ini hanya mampu menggambarkan hasil perilaku terhadap TDR dan skor SAFAR pada waktu tertentu saja, sehingga untuk penelitian selanjutnya dapat menggunakan metode longitudinal untuk mengetahui perilaku masyarakat Jember terhadap TDR dan rinitis alergi dari waktu ke waktu.

Rekomendasi yang dapat diberikan oleh peneliti terhadap pemerintah yaitu lebih meningkatkan pengetahuan tentang TDR sehingga perilaku terhadap TDR semakin baik lagi guna menurunkan kejadian penyakit rhinitis alergi melalui edukasi dan promosi kesehatan secara kontinyu terkait TDR. Meskipun rhinitis alergi tidak banyak mengakibatkan kematian, namun penyakit ini dapat menurunkan kualitas hidup seseorang serta menurunkan produktivitas, apalagi penyakit ini lebih sering terjadi pada usia produktif. Tungau Debu Rumah, seperti cara mengatasi populasi TDR, bahaya 
yang ditimbulkan akibat TDR, dan cara penanganan alergi TDR. Peneliti selanjutnya dapat melakukan pengawasan langsung atau tidak langsung agar hasil kuesioner perilaku terhadap TDR murni hasil pikiran responden tersebut, selain itu dapat dilakukan penelitian dengan desain penelitian case-control maupun cohort untuk dapat mengevaluasi upaya-upaya intervensi yang telah dilakukan guna mengontrol penyakit rhinitis alergi.

\section{DAFTAR PUSTAKA}

Alreshidi, F.M., Alrashidi, A.S., Alshammari, F.N.M., Qadi, A.B.A, Alrahidi, A.G.M., Alghaythi, S.M.S., et al., (2017). Knowledge, attitude and practice about allergic rhinitis in Saudi Arabia, 2017. Egyptian J Hospital Med, 69(4): 2199. 2203. http://doi.org/10.12816/0041516

Bousquet, J., Schunemann, H.J., Samolinski, B., Demoly, P., Baena-Cagnani, C.E., et al., (2012). Allergic Rhinitis and its Impact on Asthma (ARIA): achievements in 10 years and future needs. J Allergy Clin Immunol, 130(5), 1049-1062. http://doi.org/10.1016/ j.jaci.2012.07.053

Calderon, M.A., Linneberg, A., Kleine-Tebbe, J., De Blay, F., de Rojas D. H. F., Virchow, J.C. et al. (2015). Respiraotory allergy caused by house dust mites: What o we really know?. J Allergy Clin Immunol. 136 (1), 38-48. http://doi.org/10.1016/ j.jaci.2014.10.012

El-Ghitany, E.M. \& Abd El-Salam, M.M. (2012). Environmental intervention for house dust mite control in childhood bronchial asthma. Environ Health Prev Med, 17, 377-384. http://doi.org/10.1007/s12199-011-0263-5

European Academy of Allergy and Clinival Immunology (2014). Skin prick test procedure. https://www.eaaci.org/attachments/ allergybazaar/1\%2520SPT/

Fassio, F. \& Guagnini, F. (2018). House dust miterelated respiratory allergies and probiotics: A narrative review. Clin Mol Allergy, 16, 15. http://doi.org/10.1186/s12948-018-0092 $-9$
Frohlich, M., Pinart, M., Keller, T., Reich, A., Cabieses, B., Hohmann, C., et al. (2017). Is there a sex-shift in prevalence of allergic rhinitis and comorbid asthma from childhood to adulthood? A meta-analysis. Clin Transl Allergy, 7(44). http:// doi.org/10.1186/s13601-017-0176-5

Haqi, S. A. (2016). Prevalensi dan Derajat Infestasi Tungau Debu Rumah di Asrama Mahasiswa. Bogor: Fakultas Kedokteran Hewan Institut Pertanian Bogor. https:// repository.ipb.ac.id/ handle/123456789/84085

Hartini, S. (2016). Keanekaragaman Tungau Famili Macrochelidae (Acari: Gamasida) Pada Beberapa Tipe Penggunaan Lahan Di Kabupaten Pesawaran, Lampung, Sumatera. Zoo Indonesi, 24(1), 21-27. https:// doi.org/10.52508/zi.v24i1.2332

Hohakay, Y. A., Wahongan, G. J. P. \& Bernadus, J. B. B. (2017). Jenis dan kepadatan tungau debu rumah di Kelurahan Kleak Kecamatan Malalayang Kota Manado. Jurnal eBiomedik, 5(2), 1-11. https:// doi.org/10.35790/ebm.v5i2.16352

Irwan (2017). Etika dan Perilaku Kesehatan. Gorontalo : CV. Absolute Media

Mantu, G.G., Wahongan, G.J, \& Bernadus, J.B. (2016). Hubungan Kepadatan Tungau Debu Rumah Dengan Derajat Rinitis Alergi. Jurnal e-Biomedik, 4(1). https:// doi.org/10.35790/ebm.v4i1.11056

Mapanawang, S.G., (2013). Survey Perilaku Masyarakat Terhadap Tungau Debu Rumah Disekitar Rumah Penduduk Kelurahan Taas Kecamatan Tikala Kota Manado. Jurnal eBiomedik, 1(2). https://doi.org/10.35790/ ebm.v1i2.5476

Natalia, D. (2015). Peranan alergen tungau debu rumah (der p 1 dan der $\mathrm{p} 2$ ) dalam reaksi alergi. Cermin Dunia Kedokteran, 42(4), 251-255. http://www.cdkjournal.com/ index.php/CDK/article/view/1018

Nisa, R. (2017). Kejadian Rinitis Alergi dengan Komplikasi Otitis Media Akut pada Anak Usia 5 Tahun.J Medula Unila, 7(1), 54-59. http://juke.kedokteran.unila.ac.id/ index.php/medula/article/view/747/

Ologe, F. E., Adebola, S.O., Dunmade, A.D., Adeniji, K.A., \& Oyejola, B.A.(2013). Symptom score for allergic rhinitis. Otolaryngol 
Head Neck Surg, 148(4), 557-563. http:// doi.org/10.1177/0194599813477605

Piau, J. P., Massot, C., Moreau, D., Ait-Khaled, N., Bouayad, Z., Mohammad, Y., et al., (2010). Assessing allergic rhinitis in developing countries. Int J Tuberc Lung Dis, 14(4), 506 - 512 . https:// pubmed.ncbi.nlm.nih.gov/20202311/

Purba, S.E., Pijoh, D. \& Runtuwene, J. (2013). Survey Perilaku Masyarakat Terhadap Populasi Tungau Debu Rumah Di Kelurahan Titiwungen Selatan Kecamatan Sario Kota Manado. Jurnal e-biomedik, 1(2), 1-9. https:// doi.org/10.35790/ebm.v1i1.4365

Rafi, M., Adnan, A., \& Masdar, H. (2015). Gambaran Rinitis Alergi Pada Mahasiswa Fakultas Kedokteran Universitas Riau Angkatan 2013-2014. Jurnal online mahasiswa FK Universitas Riau, 2(2), 1-11. https://jom.unri.ac.id/index.php/JOMFDOK/ article/view/6466

Rajasekaran, V. \& Ghosh, P. (2018). Knowledge, attitude and practice about allergic rhinitis in a rural population, Kancheepuram district, Tamil Nadu. Int $J$ Otorhinolaryngology Head Neck Surgery, 4(1). https://10.18203/ issn.2454-5929.ijohns20175618

Reinhard, E., Palandeng, O. I. \& Pelealu, O. C. P. (2013). Rinitis Alergi di Poliklinik TTH-KL BLU RSU Prof. Dr. R. D. Kandou Manado Periode Januari 2010 - Desember 2012', eCliniC, 1(2): 1 - 7. https://doi.org/10.35790/ ecl.v1i2.3280
Septriana, M., Purnamasari, N., \& Studiawan, H. (2018). Allergic Rhinitical Therapy With Acupuncture, Legundi and Temulawak Herbs. Journal of Vocational Health Studies, 2(2), 60-69. http://dx.doi.org/10.20473/ jvhs.V2.I2.2018.60-66

Sulistyaningsih, E., Laili, E.F., \& Abrori, C. (2021). The Density of Dermatophagoides sp. in Households and its Correlation with the Score for Allergic Rhinitis in Jember, East Java. Mutiara Medika. 21(1), 32-38. https:// doi.org/10.18196/mmjkk.v21i1.7925

Sun, J. Shen, L., Chen, J., Yu, J., \& Tin, J. (2013). Species diversity of house dust mites in Beijing, China. J Med Entomol, 50(1), 31-36. https://doi.org/10.1603/ME12036

Susanti, E., Pawarti, D.R. \& Soeprijadi, S. (2016). Hubungan kadar RANTES sekret hidung dengan skor gejala total penderita rinitis alergi. Oto Rhino Laryngologica Indonesiana, $46 \quad$ (2), 110-120. https:// doi.org/10.32637/orli.v46i2.158

Wang, Y., Xiong, L., Yin, X., Wang, J., Zhang, Q., $\mathrm{Yu}, \mathrm{Z}$., et al., (2014). House dust mite allergen levels in households and correlation with allergic rhinitis sympoms. Am J Rhinol Allergy. 28: e193-e196. https:// doi.org/10.2500/ajra.2014.28.4095

Yolazenia, Y., Harianto, H. \& Riady, IT. (2019). Gambaran Kepadatan Tungau Debu Rumah Sebagai Pencetus Rinitis Alergi pada Anak Panti Asuhan Pekanbaru. Jurnal Ilmu Kedokteran, 13(1), 23-28. https:// doi.org/10.26891/JIK.v13i1.2019.23-27 